\title{
Economic growth as a key factor in the dynamics of level and quality of life of Ukrainian population
}

\author{
Alexander Frolov ${ }^{1} *$, Marina Kosich $^{1}$, Elena Aleksandrova ${ }^{1}$, Olga Mozgovaya ${ }^{1}$ and Olga \\ Komarenko ${ }^{2}$ \\ ${ }^{1}$ Ukrainian State University of Railway Transport, Department of Economic Theory and Law, 7, \\ Feuerbach Square, Kharkov, 61050, Ukraine \\ ${ }^{2}$ V. N. Karazin Kharkov State University, PhD student, 4, Svobody St., Kharkov, 61022, Ukraine
}

\begin{abstract}
The objective of this article is conducting the analysis of economic growth, being a key factor in the dynamics of level and quality of life of the population, as well as to develop the related suggestions, in order to accelerate and stabilize such processes in Ukraine. This research presents the analysis of the real GDP's changing rate in recent years, along with the assessment of another evidence of the economic growth - i.e. the income of the population. The related crosscountry comparative analysis of the level of population's well-being has been performed. The reasons for Ukraine's significant lagging behind its neighboring regions and other European countries in terms of main economic indicators have been determined. We've defined the "poverty trap", the authors believe that it is the current state of Ukrainian Economy. The related suggestions aimed to accelerate and stabilize the economic growth in Ukraine have been developed.
\end{abstract}

\section{Introduction.}

Nowadays, the actual improving of the population's level and quality of life is supposed to be the main goal and final result of the reproductive activity of Society. On the one hand, it is the main criterion for development of social production. Taking into consideration the achieved level and quality of life, we can assess the "quality" of the national economy, the satisfaction degree of various requirements of Society. Providing the conditions to guarantee the decent life and free personal development is a required pre-condition for the proper functioning of the Ukrainian Economy, along with the increase of its competitive ability and maintaining the social and political stability in Society. On the other hand, the current state of the population's level and quality of life depends upon the degree of development of social production and, because it is the final result at the time, if we evaluate it from this point of view.

In order to improve the level and quality of life, it is extremely important to define the factors of their dynamics. The authors used the following approach for the problem under study: it was supposed to identify and analyze the main factor in dynamics of the level and quality of life of Ukrainian population, as well as to compare it with the factors of such

\footnotetext{
* Corresponding author: afrolov27@ukr.net
} 
activities in another countries and to reveal the trends which affect the alteration of the factor itself.

The objective of this research is the analysis of such a fundamental factor in the dynamics of the population's level and quality of life as the economic growth and development of suggestions aimed at its acceleration and stabilization in Ukraine.

\section{Results and their Discussion.}

The achieved rates of economic growth characterize the state and actual rate of social and economic development of the national economy. Speaking about the worldwide tendencies, the economic growth is determined by the dynamics of changes in real GDP in dollar terms, it shows the actual increase in the amount of consumed goods and services. This factor serves as a baseline for worldwide statistics and ratings, including the living standards.

The annual data on the real GDP's dynamics are regularly published. In Ukraine this factor decreased by $11,6 \%$ [1] in 2017, as compared to the period of the year 2013. In 2018, the actual GDP growth rates have already reached 3,3\% [2]. However, this growth factor turned to be absolutely insufficient for Ukrainian Economy. Under such conditions of development rates, the country will be able to reach the level of the year 2013 in 15 years only, not earlier yet.

The experts believe that the countries which belong to the group of the "emerging markets" (including Ukraine) would need to provide the economic growth rates from 5\% to $10 \%[3,4]$, in order to succeed in solving their social and economic problems. However, according to the forecast presented by the World Bank, in 2019 the actual GDP growth in Ukraine is expected to achieve 2,9\% only, while in 2020 it could reach the level of 3,4\% and in 2021 it would achieve $3.8 \%$ [5], respectively. It's evident that even if Ukraine could have managed to achieve such growth rates, those results would not be sufficient to guarantee the sustainable development of its Economy and improve the level and quality of life of its population, either.

Nevertheless, the country's economic growth is characterized not only by the volume and dynamics of the actual GDP, but also by the size of the income value of its citizens.

In 2017 the worldwide ratings of the countries demonstrated that the results achieved by Ukraine turned out to be as follow: 1) in terms of GNI per head of population in the group of medium-income countries Ukraine was classified to the $158^{\text {th }}$ position (based on 216 countries, respectively), its index amounted to $\$ 2.310$. In order to compare the results, it's worth mentioning that: in Georgia GNI value per head of population amounted to $\$ 3.810$; in Belarus it amounted to \$ 5.600; in Bulgaria it amounted to \$ 7.470; in Russia it amounted to \$ 9.720; in Hungary it amounted to $\$ 5.170$; in Poland it amounted to \$12.680) [6]; 2) in terms of GDP value per head of population based on purchasing power parity (PPP) Ukraine was classified to the $112^{\text {th }}$ position (based on 185 countries, respectively); 3) in terms of GDP value per head of population in constant prices as of year 2010 (US dollars) Ukraine was classified to the $124^{\text {th }}$ position (based on 187 countries, respectively) [7]; 4) by nominal value per head of population (USD, \$) Ukraine was classified to the $132^{\text {nd }}$ position (based on 190 countries, respectively) [8].

In our opinion, such significant Ukraine's lagging behind its neighboring regions and other European countries, related to the key indicators that characterize the state of its Economy, which are also supposed to be the general indicators of the population's level and quality of life, first of all happen due to the orientation of its economy to be supplied with raw materials and, consequently, its considerable dependence on the world conditions of energy markets, metal products, grain crops.

The export - orientated character of the economy has been considerably justified by the export-GDP ratio in Ukrainian economy, which amounted to 47,9\% in 2017 [9]. Meanwhile, nowadays the $2 / 3$ ratio of commodity export value are the raw materials or products with low 
added value. Analysis of the dynamics of the structure of Ukrainian commodity export values demonstrated that the share of export values of machinery, equipment and transport (goods with the highest added value) in 2017 was 3,5 times less than the share of export values of agricultural products and foodstuffs, while in 2013 it was lower by 1,6 times [10] only.

In the meanwhile, the country's export structure makes significant impact upon the dynamics of indicators of its population's level and quality of life. In other words, the more products with high added value are concentrated within the country's export structure, the greater is its GDP value per head of population.

The agricultural products make nearly one third of our export turnover. The export turnover of the agricultural goods makes nearly $40 \%$ of the overall foreign exchange earnings of Ukraine. It means that the maintenance of macroeconomic stability in the country is significantly affected by the level of world prices for agricultural - industrial goods. Meanwhile, the actual ratio of the agricultural - industrial complex (AIC) within Ukraine's GDP continues to grow almost during all recent years, and nowadays it has been approaching the level of $20 \%$ already [10].

However, the higher is the level of economic development of the country, the smaller is the share of agricultural production within its GDP. For example, in terms of agricultural output, France takes the third position among the developed countries of the world and the first position in Europe, but the share of its agricultural production amounts to $2,4 \%$ of its GDP [11] only. On the contrary, the poorest countries in the world have the largest share of agricultural production. Consequently, there is a clearly evident relation between the ratio in the country's agricultural GDP (being the industry with a low level of added value) and the well-being of its population - the higher this ratio is, the lower the level and quality of life have been demonstrated.

The evident consequence of the problems of the economy oriented to the raw materials is the fact that Ukraine has been turning into one of the poorest countries in the world. In particular, according to the annual data on the world well-being presented by the Global Wealth Report, Ukraine was classified to the $123^{\text {rd }}$ position, based on 140 countries, in terms of personal wealth of its population (\$ 1.563 as of mid-year 2018) [12].

Nowadays the main characteristics of Ukrainian economy are the existence of selfgenerating mechanisms for its inner degradation and conservation of low level and quality of life of its population [13]. This factor means that the population has been involved into the "poverty trap".

The well-known Norwegian economist E. Reinert believes that in order to provide the country with an opportunity to escape from the "poverty trap" and get involved into the spiral movement of the "self-accelerating" growth of well-being, the manufacturing industry should become the dominating branch of its Economy, where the concept of "increasing returns to scale" should be applied in its sectors. This concept means that any increase in production under the circumstances of unmodified technology causes the eventual decrease in average operating costs and growth of increasing returns from additional production factors, i.e. this concept helps provide the economy of scale in production. In case if some developed manufacturing industry makes part of certain Economy (Reinert calls it the "real goldmine" [14]), it becomes the main condition for increasing the wealth of any country.

Due to the actual results of development of those branches which provide the "increasing returns to scale", the Economy undergoes such positive changes as the decrease in unemployment, income growth of the population, technological progress in some other branches of industry, along with the impact of synergy, stabilization of currency exchange rate, increase in business profitability and increase in budget receipts. We believe that economic development nowadays has been actually determined by the growth in those branches of industry which provide the "increasing returns to scale". This very concept "contains a huge potential that can increase the welfare of the whole mankind" [14].

In case if the economy has been composed of the branches of industry with predominantly decreasing "returns" of production factors (in particular, the agricultural sector is meant), "... 
then even under the actual GDP growth, the country is getting involved into a deeper "poverty trap" and is sure to stay blocked in its industrial backwardness even more. Under such circumstances, the GDP growth becomes unsustainable and can be easily transformed into eventual economic collapse, along with the depreciation of the national currency, escalation of inflation, increasing stratification of society depending of the people's income, because the bulk of the population becomes even poorer, and, consequently, we evidence those crises and revolutions that happen with greater frequency" [13].

Ukraine needs a new concept to provide it with rapid and sustainable economic growth, with obligatory revival of manufacturing branches of industry and new industrialization. This condition for successful implementation of this strategy will help it escape from the "poverty trap".

The essential first step in this direction means the further refusal from the dominating liberal paradigm, because it stands for refusal of the required and widespread governmental intervention into Economy. This system of economic views which forms the basis for the recommendations provided by the International Monetary Fund (IMF) and the World Bank, would not meet the actual modern realities, so, it has been rejected by the industrialized countries long ago.

The experience of the developed countries of Europe and the USA demonstrates that they have made a dramatic "strike" in their industrial development despite (and not due to) those liberal theories.

For decades, the developed countries used to implement the policy of banning or restricting the export operations dealing with raw materials, rejection to deal with the goods of "decreasing returns to scale", as well as they used to establish, protect and develop the domestic manufacturing industry. It is precisely because of this economic policy that they have managed to make the industrial "breakthrough" and become wealthy and prosperous countries.

It goes without saying that, first of all, the economic policy of Ukraine should reject the liberal theoretical recommendations and become oriented to the proposals based on the Keynesian and institutional theories of government regulation of its economy. A new concept of sustainable economic growth in Ukraine implies the pro-active economic government policy.

Nowadays, the countries that have achieved a high level of competitiveness and sustainable economic growth are those ones which provided the basis for their innovative economic development, yet they are not those countries which are the current leaders in the fields of extraction and sale of natural resources. The innovations have become the main source of economic growth. According to the opinion by E. Reinert, those "innovations, and not the savings and the capital itself, promote the well-being" [14]. The "trigger" for the innovations in contemporary economy is the manufacturing industry, with its core factor - i.e. the engineering, being the value-added activity.

Firstly, the significance of engineering has been specified by the fact that, being the most innovative branch of industry, it plays a key role in determining the level, dynamics and nature of development of productive powers of Society. Any achievements in technical and technological progress in Economy, consequently, improve the population's level and quality of life, and they would be impossible without developing the engineering sector.

In terms of economic development in the fields of innovations and technological achievements, Ukraine significantly lags behind both the industrialized and actively developing countries. The extremely low social productivity of labor is the logical consequence of the current situation. According to this factor, our country at this time lags behind not only the developed European countries (in 4 - 6 times), but its development is lower than the dynamics of Bulgaria, which is one of the poorest countries in the European Union (in more than 2 times) [15]. It should be noted if such a "gap" is not going to be "closed" in the coming 15 years, then, obviously, Ukraine would have never get any 
opportunity to catch up with not only industrialized European countries, but with actively developing countries, either.

The engineering branch serves as a basis for technical re-equipment of the entire Economy. It comprises the high-tech and knowledge-based industry to its maximum extent and, besides, it is able to create the advanced instruments of labor and technologies to be applied not only in all the other branches of industry, but also in the leading sectors of the whole national economic complex. It is precisely the way how the level of development of engineering makes its basic influence upon the growth of social productivity of labor.

Under the current circumstances, the engineering branch plays its "locomotive" role in the development of Economies of the leading countries of the world. The structure of industrial production of those countries contains the engineering/machine-building ratio equal up to 35 $50 \%$ (in Germany it amounts to 53,6 \%, in Japan it amounts to 51,5\%, in England it amounts to $39,6 \%$, in Italy it amounts to $36,4 \%$, in China it amounts to $35,2 \%$ ) [16]. (In order to compare: in Ukraine the ratio of engineering/machine-building ratio complex within the structure of industrial production is less than $14 \%$ ) [17, pp. 98-99].

The governmental policy in the field of innovations in industrialized and actively developing countries is aimed at providing the most favorable conditions to improve the performance of engineering/machine-building industry as the basis for increasing the innovative efficiency of the whole Economy.

One of the most important factors of the efficiency of innovative activity in engineering/machine-building sector is the cost component for Research and Advanced Development (R\&D) issues. For example, in the United States, the share of machine-building sector is equal up to $20 \%$ of all R\&D issues, and the annual investment amount in R\&D in the field of engineering is $2,0-2,5 \%$ of GDP value. In EU countries, the average share of the annual expenditures on R\&D in engineering/machine-building sector is up to 3\% of GDP value [17, p. 94]. In Ukraine this factor (even at the mid-2000-ies, those years were the best period in terms of economic growth rates) was indicated at the level of $0,1 \%$ of GDP value [18].

The process of reforming the Ukrainian engineering/machine-building industry should be realized in several directions. Firstly, it's necessary to create the efficient mechanisms, in order to stimulate the investment promotion for modernization and technical re-equipment of the traditional branches of its industry (for example, introduction of special tax regime, when the tax rate for the enterprises of those branches should depend on the amount of investments into brand - new machinery and R\&D issues). Secondly, it's necessary to develop strategies and mechanisms for managing the innovation processes at the machine-building enterprises, in order to ensure the priority development of knowledge-based and innovative technological processes for manufacturing the products with high value-added ratio.

\section{Conclusions.}

Nowadays, the priority focus has been set to the growth of agricultural industry, along with simultaneous neglecting of the problems related to the developing industrial potential; first of all, it will inevitably turn Ukraine into one of the countries of the world with an extremely low level and quality of life of its population, and, secondly, it is going to confirm the status of this country, being a "raw materials appendix" within the world economy.

The strategy for transition of Ukrainian economy from the raw-materials' export model to a competitive-and-innovative development model should be based upon acceptance of the need of thorough governmental intervention into the Economy. The governmental economic policy should be aimed at stimulating the development of high-tech industries that produce the competitive products with high value-added ratio, and first of all, we're speaking about the engineering/machine-building industry here. 
The priority development of machine-building industry, which is the key source of the innovative development of Ukrainian Economy, should result in the revival of high-tech industrial facilities and stimulating the domestic consumer's demand.

The most important outcome of transition to a new economic development model will be the provision of sustainable economic growth in Ukraine, and, consequently, the positive dynamics in the level and quality of life of its population.

\section{References}

1. World Bank. Available at:

http://pubdocs.worldbank.org/en/300571492021934576/data-ukr.pdf

2. National Bank of Ukraine. Inflation Report (January, 2019) . Available at: https://bank.gov.ua/control/uk/publish/article;jsessionid=D9941BD17ED1C1912CB72F A744C2DA84?art id $=63442015 \&$ cat $i d=742185$

3. "Europe Does Not Need Domestic Economy": Why is Ukrainian Economy is Increasingly Involved into Stagnation? Available at: https://nk.org.ua/ekonomika/evropepromyishlennost-stranyi-ne-nujna-pochemu-ekonomika-ukrainyi-vse-bolshepogrujaetsya-v-stagnatsiyu-141690

4. P. Vernivskiy. New Time. - March, 26 (2018). - Available at: https://biz.nv.ua/experts/chto-ne-tak-s-rostom-vvp-2460126.html

5. World Bank. Available at: http://pubdocs.worldbank.org/en/426991542818421034

/Global- Economic -Prospects-Jan-2019-Regional-Overview-ECA-RU.pdf

6. World Country Ranking in Terms of Gross National Income per Head of Population / Humanitarian Encyclopedia Available at: https://gtmarket.ru/ratings/rating-countriesgni/rating-countries-gni-info

7. World Data Atlas. Available at: https://knoema.ru/atlas

8. World Country Ranking in terms of GDR per head of population in 2017. Available at: http://investorschool.ru/rejting-stran-po-vvp-na-dushu-naseleniya-2017

9. State Statistics Committee of Ukraine. [Electronic resource]. - Available at: http://www.ukrstat.gov.ua/

10. State Tax Service of Ukraine. Available at: http://sfs.gov.ua/ms/f2

11. Structure and Features of French Economy / Economics, Belorussian State Economic University. Available at: https://www.economy-web.org/?p=382

12. Ukraine Was Classified the $123^{\text {rd }}$ Position in Terms of Well-Being of its Population. Available at: https://news.finance.ua/ru/news/-/436881/ukraina-zanyala-123-mesto-vmire-po-urovnyu-bogatstva-grazhdan

13. T. Unkovskaya. Mirror of the Week. 6, (2016). Available at: https://zn.ua/macrolevel/kak-ukraine-vyrvatsya-iz-lovushki-bednosti- .html

14. Reinert E. How Rich Countries Got Rich and Why Poor Countries Stay Poor Available at: http://uaterra.in.ua/wp-content/uploads/2017/11/Rajnert-Eryk.pdf

15. International Labour Organization. Available at: https://www.ilo.org/global/lang-en/index.htm

16. Polovinkin V.N., Fomichev A.B. Actual State and Problems of Development of Domestic Engineering Industry. Available at: http://www.proatom.ru/modules.php ?name $=$ News \&file $=$ print $\&$ sid $=4639$

17. Gerasimchuk V.I. Marketing and Management of Innovations. 3, 84-104 (2015). Available at: http://mmi.fem.sumdu.edu.ua

18. Danilishin B. New Time - April, 24 2015. - Available at: https://nv.ua/opinion/kakostanovit-agoniyu-ukrainskoy-ekonomiki-45647.html 